\title{
The ecosystem services supplied by soil in relation to land use
}

\author{
Jarmila MAKOVNÍKOVÁ ${ }^{1}$, Radoslava KANIANSKA² and Miriam KIZEKOV Á ${ }^{3}$
}

\begin{abstract}
The concept of ecosystem services has become an important tool for modelling interactions between ecosystems and their external environment in terms of global bio-climatic changes. The provision of ecosystem services depends on biophysical conditions and changes over space and time due to human induced land cover and land use. Ecosystem services linked to natural capital can be divided into three services categories (provisioning, regulating and cultural), and ecosystem functions (structures and processes relevant for ecosystem self-organisation, biodiversity, soil macro-organisms, micro-organisms) must be added. Traditionally, agroecosystems have been considered primarily as sources of provisioning services, but more recently their contributions to other types of ecosystem services have been recognized. Agroecosystems can provide a range of other regulating and cultural services to human communities, in addition to provisioning services and services in support of provisioning. Six agricultural study areas, each of them with two different land use categories (arable land and permanent grasslands) located in various natural conditions of Slovakia, were evaluated. For the analysis of the agroecosystem services seven study sites were selected on the basis of the following criteria: 1) polluted area (inorganic contamination); 2) non polluted area (without the inorganic contamination); 3 ) area threatened by erosion; 4) abandoned land; 5) low productive land; 6) productive land. For each locality two study sites were selected: arable land with annual plant and permanent grassland. The greatest differences can be seen in the relation to land use and diversity of soil types. The agroecosystem services potential value of arable land and grassland sites located in different soil-ecological regions of Slovakia differ in all categories of services. The most significant differences are in provisioning and regulating services. Our results confirm significant negative correlation only between provisioning and cultural agroecosystem services
\end{abstract}

Keywords: agroecosystem services, filtration potential, sorption potential of soil, soil organic carbon, grassland, arable land

\section{Introduction}

The concept of ecosystem services has become an important tool for modelling interactions between ecosystems and their external environment in terms of global bioclimatic changes. The provision of ecosystem services depends on biophysical conditions and changes over space and time due to human induced land cover and land use. Ecosystem services linked to natural capital can be divided into three services categories (provisioning, regulating and cultural) adding ecosystem functions (structures and processes relevant for ecosystem self-organisation, biodiversity, soil macro-organisms, micro-organisms) (DomINATI, E. et al. 2010; Burghard, B. et al. 2014). Nevertheless, few studies on ecosystem services are conducted in agroecosystems (FELD, C.K. et al. 2009; VihervaAra, P. et al. 2010). Agroecosystems are managed to fulfil basic human needs, such as food and raw materials (ZHANG, W. et al. 2007).

According to several authors (DAILY, G.C. 1997; Power, A.G. 2010) agroecosystems can provide a range of other regulating and cultural services to human communities, in addition to provisioning services and services in support of provisioning. Traditionally, agroecosystems have been considered pri-

\footnotetext{
${ }^{1}$ National Agricultural and Food Centre/ Soil Science and Conservation Research Institute Bratislava, Regional Station Banská Bystrica, Slovakia. E-mail: j.makovnikova@vupop.sk. Correspondent author.

${ }^{2}$ Matej Bel University Banská Bystrica, Faculty of Natural Sciences, Department of Environment.

${ }^{3}$ National Agricultural and Food Centre, Grassland and Mountain Agriculture Research Institute, Banská Bystrica.
} 
marily as sources of provisioning services, but more recently their contributions to other types of ecosystem services have been recognized (MEA 2005).

A number of recent studies have mapped the supply of services at global (Naidoo, R. et al. 2008), continental (Schulp, C.E.J. et al. 2012), national (BATEMAN, I.J. et al. 2011) or regional scales. The most common indicators for modelling ecosystem services are land use cover, soils, vegetation and nutrient related indicators. However, provisioning services are mapped more frequently than regulating and cultural service (CROSSMAN, N.D. et al. 2013).

The work presented in this paper aims at the ecosystem service potential supplied by agroecosystem in relation to land use.

\section{Material and methods}

Seven agricultural study areas, each of them with two different land use categories (arable land and grasslands) located in various natural conditions of Slovakia, were evaluated. The study sites suitable for the agroecosystem service analysis were selected on the basis of the following criteria: 1) non polluted area, 2) polluted area (with inorganic contamination), 3) low productive area, 4) land threatened by erosion, 5) medium productive land, 6) abandoned land, 7) productive land (Table 1).

The basis for analysing the potential for the provisioning agroecosystem services was a point value $(B H)$ of productive potential based on typological and production classification of agricultural soil of Slovakia:

$$
B H=(H P J+S E+K H+Z) \times T,
$$

where $H P J=$ point value of the main soil unit, $S E=$ inclination score and exposure score, $\mathrm{KH}$ = score of skeleton and soil depth, $Z=$ texture score, $T=$ coefficient for climatic regions. The $B H$ value is a basis for the rationalization and environmental exploitation of natural resources of a particular territorial unit and its value in Slovakia ranges from 0 to 100 .

Regulating services, soil filtration potential $(F P)$ - or immobilisation potential ( 5 categories) was calculated as accumulative function:

$$
F P=S P+K,
$$

where $S P=$ sorption potential of soil, $K=$ potential of total content of inorganic contaminants evaluated according to the Slovak Law 220/2004 Z. z. (МакоvNíkovÁ, J. et al. 2007).

Point evaluation of sorption potential of soil (SP) was calculated as a sum of two different factors:

$$
S P=F(p H)+F(Q 46)+F(\operatorname{Cox}) \times F(H),
$$

where $F(p H)$ and $F(Q 46)$ are quantitative factors, $F(C o x)$ and $F(H)$ are qualitative ones according to function. $H=$ depth of humus horizon.

Soil organic carbon $(S O C)$ is a part of soil organic matter (SOM). Soil organic carbon was determined on C,N analyser EA. Soil carbon stock (SOCS - in t/ha) (5 categories) was calculated like function:

$$
\text { SOCS }=10 \times S O C 1 \times B D 1,
$$

Table 1. Study sites characteristics

\begin{tabular}{c|l|c|c|c|c|l}
\hline $\begin{array}{c}\text { Study } \\
\text { sites }\end{array}$ & Geographical location & $\begin{array}{c}\text { Altitude, } \\
\text { m a.s.l. }\end{array}$ & Climate & Inclination & $\begin{array}{c}\text { Distance to } \\
\text { the roads, } \mathrm{m}\end{array}$ & Soil type \\
\hline ST & Eastern Slovak Hills & 121 & 02 & $0^{\circ}$ & $100-200$ & Fluvisol \\
ME & Krupina Plain & 151 & 04 & $0^{\circ}$ & $100-200$ & Fluvisol \\
ZA & Borská Lowland & 170 & 00 & $2^{\circ}$ & $100-200$ & Regosol \\
CO & Slovak Karst & 354 & 06 & $7^{\circ}$ & $200-500$ & Cambisol \\
TA & Kremnica Mountain & 647 & 07 & $2^{\circ}$ & $100-200$ & Cambisol \\
VI & Low Tatras & 945 & 08 & $5^{\circ}$ & $>500$ & Rendzina \\
ZE & Danube Slovak Hills & 136 & 01 & $2^{\circ}$ & $>500$ & Chernozem \\
\hline
\end{tabular}

*ST = Stráňany, ME = Medovarce, ZA = Závod, CO = Čoltovo, ZE = Zeleneč, TA = Tajov, VI = Vikartovce. 
where $S O C 1=$ soil organic carbon content in per cent in the depth $0-10 \mathrm{~cm}, B D 1=$ soil bulk density in the depth $0-10 \mathrm{~cm}$ in $\mathrm{g} / \mathrm{cm}^{3}$ (Barančíková, Makovníková, VP VUPOP 2013). The categories are as follows: $1=$ very low potential (lower than 20 t SOC /ha), $2=$ low potential (20-40 t $S O C /$ ha), $3=$ medium potential (40-60 t SOC /ha), 4 = high potential (60-80 t SOC /ha), 5 = very high potential (more than $80 \mathrm{t} S O C / \mathrm{ha}$ ). The loss of soil by erosion was evaluated with the RUSLE model.

The potential for outdoor recreation $(R P)$ (cultural ecosystem services) was evaluated. We presume that each agroecosystem has the potential (capacity) for carrying out the outdoor recreation. All agroecosystems are considered to be potential providers of these services. Recreation potential was evaluated through agroecosystems landscape components that have a specific link with summer, winter and year-round recreation. The recreational potential for all these activities was calculated as sum of individual recreational activities potential without added points (Natura 2000) which were added only to the final sum in order to prevent multiple evaluations of additional factors (МАкоvNíková, J. et al. 2016).

In the analysis of the suitability of the area in terms of recreational usage, the altitude, inclination, drainage, precipitation, temperature (climate) and their distance to the roads were taken as basis. Five categories of agroecosystem to provide outdoor recreational activity were determined: 1 = very low, 2 = low, 3 = medium, $4=$ high and $5=$ very high relevant capacity.

\section{Results and discussion}

\section{Provisioning services in relation to cultural services}

Despite the fact, that all agroecosystems are considered to be potential providers of all ecosystem services, primary services of arable land are provisioning services (Figure 1).

At arable land, provisioning services are in opposite to cultural services. Our results

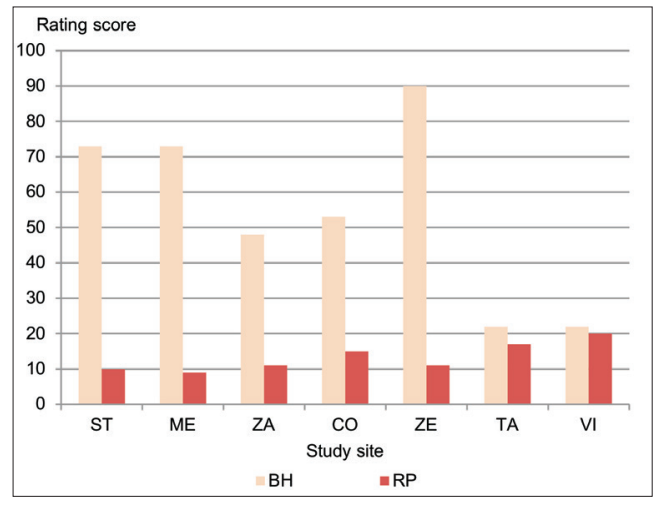

Fig. 1. Provisioning services $(\mathrm{BH})$ in relation to cultural services (RP) for arable land. Study sites: $\mathrm{ST}$ = Stráňany; $\mathrm{ME}=$ Medovarce; ZA = Závod; $\mathrm{CO}=$ Čoltovo; $\mathrm{ZE}=$ Zeleneč; $\mathrm{TA}=$ Tajov; $\mathrm{VI}=$ Vikartovce.

showed that study sites Stráňany, Medovarce and Zeleneč have higher provisioning potential compared to outdoor recreation potential. Their provisioning services have the first order priority with the exception of the site Medovarce. This study site is polluted area (by inorganic contamination). The soil is not able to fulfil its hygienic function. Therefore, crops grown on the soil cannot be used for human consumption. The locality is more suitable as grassland or for production of energy crops.

Agricultural utilisation can contribute to ecosystem services, but can also be a source of disservices as we observed in the $\mathrm{CO}$ study site. CO study site is threatened by erosion. The ecosystems affect the water balance through two processes, interception and infiltration. The interception depends on the structure of the ecosystem, on the land cover. It would be appropriate to change the land use of this locality and use this area as grassland. Study sites Tajov and Vikartovce have low provisioning potential and their use as arable land has only local significance.

Grasslands are considered to be not only actual providers of provisioning services but also actual providers of cultural services. The capacity of grasslands to provide provisioning services in relation to outdoor recreational activity is shown on Figure 2. 


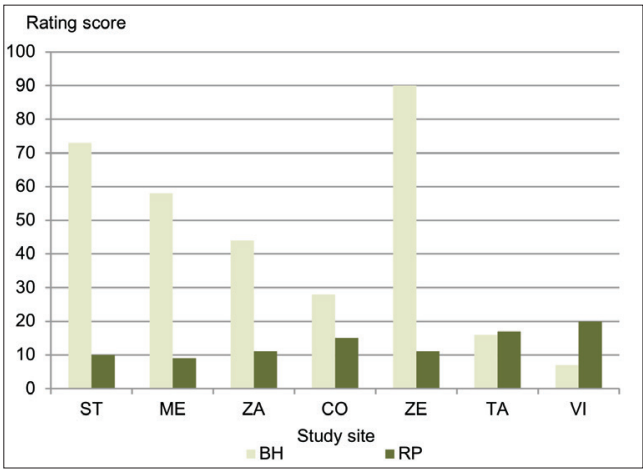

Fig. 2. Provisioning services $(\mathrm{BH})$ in relation to cultural services (RP) for grassland. For ST, ME, ZA, CO, ZE, TA and VI = see Fig 1 .

The altitude negatively affects the potential to provide provisioning services, on the other hand, positively affects the potential of cultural services.

The capacities of grasslands to supply cultural agroecosystem services can significantly contribute to the economic stability and prosperity of a particular region. The utilisation of soils with low production potential (Tajov and Vikartovce) primary for the recreational purposes can help to prevent degradation and loss of agricultural soil.

\section{Regulating services}

The categories of regulating services (soil filtration potential and soil carbon stock) are shown on Figure 3 (arable land) and Figure 4 (grassland).

It is well known that the variation in soil properties such as $\mathrm{pH}$, organic matter content and quality, texture, the quantity and quality of adsorbing sites, can significantly influence the distribution as well as availability of inorganic risk elements to plants and water (МакоvNíková, J. et al. 2007; Bujnovsky, R. et al. 2009). Potential of soil to immobilisation and thus transport of risk elements is dependent on total amount of these elements in soil and the potential of soil sorbents responsive to risk elements behaviour and availability.

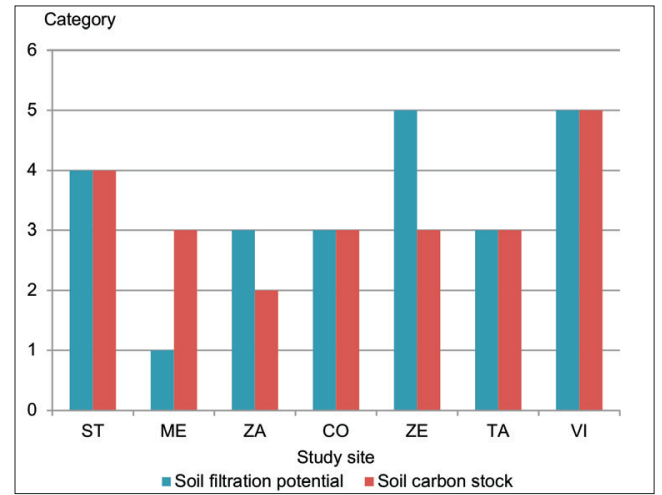

Fig. 3. Categories of soil regulating services for arable land. 1 = very low; 2 = low; 3 = medium; 4 = high; 5 = very high potential. For ST, ME, ZA, CO, ZE, TA and $\mathrm{VI}=$ see Fig 1 .

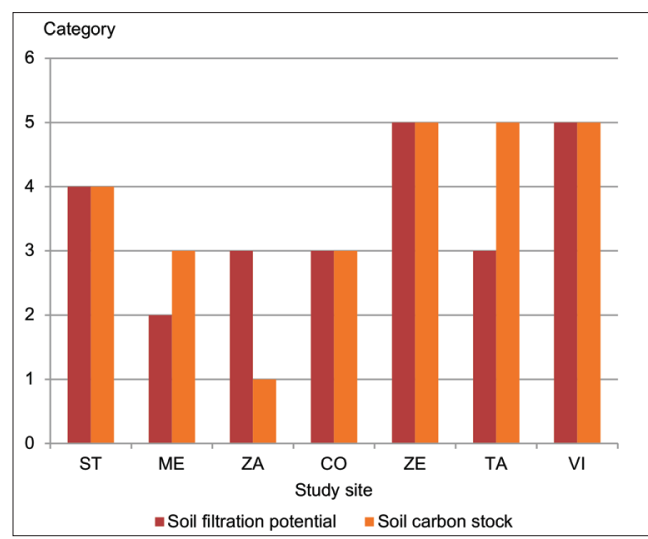

Fig. 4. Categories of soil regulating services for grassland. 1 = very low; 2 = low; $3=$ medium; $4=$ high 5 = very high potential. For ST, ME, ZA, CO, ZE, TA and $\mathrm{VI}=$ see Fig 1 .

Results of soil filtration potential showed that very high soil filtration potential has been evaluated for Vikartovce site (arable land as well as grassland). At Vikartovce site, the value of soil reaction is in neutral or slightly alkaline range. There is high content of organic matter in the surface horizon of the soil, which decreases with depth. The study site belongs to the areas with soil with high potential of soil sorbents and very low potential of risk elements evaluated in accordance with the Slovak Law 220/2004. Overall, regulating services are the lowest at the degraded study site Medovarce (site loaded with inorganic pol- 
lutants). At this study site, the high contamination is connected with a higher amount of potential risk elements in sediment deposited on the flood plains as well as with local anthropogenic sources (mining activities).

Very high potential to immobilisation of risk elements was recorded in 19.74 per cent of Slovak agricultural soils, high potential in 26.06 per cent, medium in 27.38 per cent, low in 21.64 per cent and very low potential to immobilisation of risk elements only in 5.18 per cent. Categories with very high and high immobilisation potential, thus, with low risk of inverse process, transport of risk elements, comprise 45.80 per cent of all agricultural soils of Slovakia (МАкоvNíková, J. et al. 2007).

At arable land, the stocks of soil organic matter decreases in the order Vikartovce $>$ Stráňany $>$ Tajov $=$ Medovarce $=$ Zeleneč $=$ Čoltovo > Závod.

Our results showed some different results for grassland. Higher SOC values on grassland in comparison to arable land are typical for all soil types of Slovakia (BARANČíKOvÁ, G. 2014) and it is conform with many literature data (SANFord, G.R. 2014; Gelaw, M.A. et al. 2014). The highest soil organic carbon stock has been determined at grassland localities Vikartovce, Zelenec and Tajov. The lowest stocks of soil organic matter were calculated for locality Zavod, due to the strong mineralization of organic matter that is determined by good aeration and drainage.
Soil carbon stocks are determined primary by the soil forming processes and the secondary by land use and management. Management regime governs the carbon storage. Conversion of grassland to cropland can release $0.90 \mathrm{Mg} \mathrm{C} /$ ha per year in average during a 20-year period. Conversion of arable land to permanent grassland generally results in $0.49 \mathrm{Mg} \mathrm{C} /$ ha per year carbon storage over 20 years (Hönigova, I. et al. 2012). According to Conant, R.T. et al. (2001) extensive grasslands constitute an important reservoir for atmospheric carbon. Our results confirm significant negative correlation only between provisioning and cultural agroecosystem services (Table 2).

\section{Conclusion}

The agroecosystem services potential value of arable land and grassland sites located in different soil-ecological regions of Slovakia differ in all categories of services. The most significant differences are in provisioning and regulating services. Agricultural management practices are the key for realizing the benefits of ecosystem services, especially if trying to induce synergism effect. In other words, a synergism occurs when ecosystem services interact with one another in a multiplicative or exponential fashion (Felipe-Lucia, M.R. 2014).

These can be positive, i.e. multiple services improving in provision. Explicit modelling

Table 2. The correlation analysis of agroecosystem services

\begin{tabular}{|c|c|c|c|c|c|}
\hline \multirow{3}{*}{\multicolumn{2}{|c|}{$\begin{array}{l}\text { Correlation coefficient/ } \\
\text { agroecosystem services }\end{array}$}} & \multicolumn{4}{|c|}{ Correlation coefficient } \\
\hline & & \multirow{2}{*}{$\begin{array}{l}\text { Provisioning } \\
\text { services }\end{array}$} & \multicolumn{2}{|c|}{ Regulating services } & \multirow{2}{*}{$\begin{array}{l}\text { Cultura } \\
\text { services }\end{array}$} \\
\hline & & & $\begin{array}{c}\text { Soil filtration } \\
\text { potential }\end{array}$ & $\begin{array}{c}\text { Soil carbon } \\
\text { stock }\end{array}$ & \\
\hline \multicolumn{6}{|c|}{ Arable land } \\
\hline \multicolumn{2}{|c|}{ Provisioning services } & 1.00 & 0.03 & -0.41 & -0.84 \\
\hline $\begin{array}{l}\text { Regulating } \\
\text { services }\end{array}$ & $\begin{array}{l}\text { Soil filtration potential } \\
\text { Soil carbon stock }\end{array}$ & $\begin{array}{r}0.03 \\
-0.41 \\
\end{array}$ & $\begin{array}{l}1.00 \\
0.62 \\
\end{array}$ & $\begin{array}{l}0.62 \\
1.00\end{array}$ & $\begin{array}{l}0.35 \\
0.56\end{array}$ \\
\hline \multicolumn{2}{|c|}{ Cultural services } & -0.84 & 0.35 & 0.56 & 1.00 \\
\hline \multicolumn{6}{|c|}{ Grassland } \\
\hline \multicolumn{2}{|c|}{ Provisioning services } & 1.00 & -0.35 & -0.61 & -0.85 \\
\hline $\begin{array}{l}\text { Regulating } \\
\text { services }\end{array}$ & $\begin{array}{l}-0.35 \\
-0.61\end{array}$ & $\begin{array}{c}1.00 \\
-0.39\end{array}$ & $\begin{array}{c}-0.39 \\
1.00\end{array}$ & $\begin{array}{l}0.05 \\
0.57\end{array}$ & $\begin{array}{l}0.35 \\
0.56\end{array}$ \\
\hline \multicolumn{2}{|c|}{ Cultural services } & -0.85 & 0.05 & 0.57 & 1.00 \\
\hline
\end{tabular}


of agroecosystem services is considered to be one of the main requirements for the implementation of the concept of these services in institutional decision-making. The assessment of the potential of the country to provide agroecosystem services allows us to evaluate the impacts of land use change on the capacity to adapt AESS and management for local conditions.

Acknowledgement: The authors acknowledge the Slovak Research and Development Agency for the financial support via contract No. APVV-0098-12 Analysis, modelling and evaluation of agroecosystem services.

\section{REFERENCES}

BARANČí́xovÁ, G. 2014. Monitoring of quantitative and qualitative composition of soil organic mater. In Soil monitoring of the Slovak republic. Actual state and development of monitoring soil properties as the basis for their protection and land use (the period 2007-2012). Ed.: KoвzA, J., Bratislava, NPPC-VUPOP, 53-89.

Bateman, I.J., Day, B.H., Jones, A.P. and Jude, S. 2009. Reducing gain-loss asymmetry: A virtual reality choice experiment valuing land use change. Journal of Environmental Economics and Management 58. 106-118.

Bujnovský, R., Balkovič, J, Barančíková, G., Makovníková, J., ViLČEK, J. 2009. Assessment and valuation of ecological functions of agricultural land in Slovakia. Bratislava, VUPOP.

Burkhard, B., Kandziorai, M.S. and Müller, F. 2014. Ecosystem Service Potentials, Flows and Demands - Concepts for Spatial Localisation, Indication and Quantification. Official Journal of the International Association for Landscape Ecology. Regional Chapter Germany. http://dx.doi.org/10.3097/LO. 201434. Accessed 21.02.2015.

Conant, R.T., Paustian, K. and Elliott, E.T. 2001. Grassland Management and Conversion into Grassland Effects on Soil Carbon. Ecological Applications 11. 343-55.

Crossman, N.D., Burkhard, B., Nedkov, S., Willemen, L., Petz, K., Palomo, I., Drakou, E.G., Martín-Lopez, B., McPhearson, T., Boyanova, K., Alkemade, R., Egoh, B., Bunbar, M.B. and Maes, J. 2013. A blueprint for mapping and modelling ecosystem services. Ecosystem Services 4. 4-14.

DAILy, G.C. ed. 1997. Nature's services: societal dependence on natural ecosystems. Washington, DC, Island Press.

Dominati, E., Patterson, M. and Mackay, A. 2010. A framework for classifying and quantifying the natural capital and ecosystem services of soils'. Ecological Economics 69. 1858-1868.
Feld, C.K., Martins da Silva, P., Paulo Sousa, J., De Bello, F., Bugter, R. and Grandin, U. 2009. Indicators of biodiversity and ecosystem services: a synthesis across ecosystems and spatial scales. Oikos 118. 1862-1871. Doi: 10.1111/j.1600-0706.2009.17860.x

Felipe-Lucia, M.R., Comin, F.A. and Bennett, E.M. 2014. Interactions among ecosystem services across land uses in a floodplain agroecosystem. Ecology and Society 19. (1): 20. http://dx.doi.org/10.5751/ ES-06249-190120. Accessed 21.02.2015.

Gelaw. M.A., Singh. B.R. and Lal. R. 2014. Soil organic matter and total nitrogen stocks under different land uses in semi-arid watershed in Tigray, Northern Ethiopia. Agriculture, Ecosystems and Environment 118. 256-263. http://dx.doi. org/10.1016/j. agle. Accessed 03.02.2014.

Hönigova, I. et al. 2012. Survey on grassland ecosystem services. Report to the EEA European Topic Centre on Biological Diversity. Prague, Nature Conservation Agency of the Czech Republic.

Makovníková, J., Barančíková, G. and PÁLKa, B. 2007. Approach to the assessment of transport risk of inorganic pollutants based on the immobilisation capability of soil. Plant, Soil and Environment 53. (8): 365-373.

Makovníková, J., Kanianska, R. and Kizeková, M. 2015. An approach to evaluating potential of cultural agroecosystem services. Ecology and Safety 9. 24-33.

MEA 2005. Millennium ecosystem assessment. In Ecosystems and human well-being: biodiversity synthesis. Washington, DC, World Resources Institute.

Naidoo, R., Balmford, A., Costanza, R., Fisher, B., Green, R.E., Lehner, B., Malcolm, T.H., and Ricketts, T.H. 2008. Global mapping of ecosystem services and conservation priorities. Proceedings of the National Academy of Sciences of the USA 105.9495-9500.

Power, A.G. 2010. Ecosystem services and agriculture: trade-offs and synergies'. Philosophical Transactions of the Royal Society B 365. 2959-2971.

SANFrord. G.R. 2014. Perennial grasslands are essential for long term SOC storage in the Mollisols of the North Central USA. In Soil Carbon. Eds.: Hartemink, A. and McSweeney, K., Heildelberg, Springer Cham, 281-288.

Schulp, C.J.E., Alkemade, R., Goldewijk, K.K. and Petz, K. 2012. Mapping ecosystem functions and services in Eastern Europe using global-scale data sets. International Journal of Biodiversity Science, Ecosystem Services and Management 8. (1-2): 156-168.

Vihervaara, P., Kumpula, T., Tanskanen, A. and Burkhard, B. 2010. Ecosystem services - A tool for sustainable management of human-environment systems. Case study Finnish Forest Lapland. Ecological Complexity 7. (3): 410-420.

Zhang, W., Ricketts, T.H., Kremen, C., Carney, K. and Swinton, S.M. 2007. Ecosystem services and disservices to agriculture. Ecological Economics 64. 253-260. 